\title{
Physical properties of the seasonal snow cover in Dronning Maud Land, East Antarctica
}

\author{
Eija Kärkäs, ${ }^{1}$ Hardy B. Granberg, ${ }^{2}$ Kimmo Kanto, ${ }^{1}$ Kai Rasmus, ${ }^{1}$ Chantale Lavoie, ${ }^{2}$ \\ Matti LeppäRAnta ${ }^{1}$ \\ ${ }^{1}$ Division of Geophysics, Department of Physical Sciences, University of Helsinki, P.O. Box 64, FIN-00014 Helsinki, Finland \\ ${ }^{2}$ Centre d'Applications et de Recherches en Telédétection (CARTEL), Université de Sherbrooke, Sherbrooke, Québec J1K 2RI, Canada
}

\begin{abstract}
Snow stratigraphy was analyzed in the Maudheimvidda area of western Dronning Maud Land, East Antarctica, during austral summer 1999/2000 as a part of the Finnish Antarctic Research Programme (FINNARP). Measurements were made in shallow $(1-2 \mathrm{~m})$ snow pits along a $350 \mathrm{~km}$ transect from the coast to the polar plateau, covering at least one annual cycle and an elevation range from sea level to about $2500 \mathrm{~m}$. The aim of the study is to document spatial and temporal variations in snow-cover properties, with the further aim of relating these variations to environmental factors and to patterns observable by remote sensing. The measurements suggest five principal snow zones: (i) sea ice, (ii) the seaward edge zone of the ice shelf, (iii) the inner parts of the ice shelf, (iv) the snow cover above the grounding line and $(v)$ the local topographic highs. Local topographic highs such as ice domes and ice rises differ from other snow environments: the snow is less densely packed, possibly an indication of locally reduced speed of the katabatic outflow. Fewer and thinner crusts on the topographic highs are consistent with RADARSAT backscatter variations.
\end{abstract}

\section{INTRODUCTION}

Snow blankets some $98 \%$ of all surfaces in Antarctica, including the ice cover on the surrounding seas. The top layer is a "seasonal snow cover", a term we use here to denote the snow cover deposited over the latest annual cycle. The properties of this seasonal snow cover need to be adequately represented in climate models (Smith and others, 1998; Bailey and Lynch, 2000a, b). The rate of cold air production is controlled by Antarctica's snow-covered terrain which through its katabatic effects renders the downwelling of air into the Antarctic anticyclone much stronger than that in any of its high-latitude counterparts in the Northern Hemisphere (Van den Broeke and Bintanja, 1995). Both the radiative and the turbulent fluxes at the surface of a snow cover depend strongly on its surface roughness. This property too is a difficult one to assess, for snow surface roughness is directionally, spatially and temporally variable (Bintanja and Van den Broeke, 1995).

One way in which the snow-cover properties can be assessed spatially is by satellite remote sensing (Orheim and Lucchitta, 1988, 1990; Bindschadler, 1998). With only limited ground truth, however, it is often difficult to interpret the remotely sensed information. The way in which solar radiation is absorbed and reflected can be readily observed by satellite-based remote sensing, but it is known that the anisotropic reflectance properties of snow vary on both a daily and a more long-term basis (Winther, 1993). Similarly, our own preliminary observations show that the thermal emission from a snow surface is not necessarily isotropic. Repeat imaging by RADARSAT at the South Pole shows that microwave backscatter and, by extension, microwave emission can also be highly anisotropic (personal communication from K. C. Jezek, 1999).
The aim of our present work is to obtain baseline surface data on the properties of the snow cover and on how they vary spatially with environmental variables such as distance from the sea and altitude. To develop better knowledge of the wintertime snow conditions and of possible factors influencing radar backscatter, we also examine the internal structure of the snow cover. The present project, "Seasonal Snow in Antarctica", was initiated for this purpose. The first field season took place during austral summer 1999/2000, as part of the Finnish Antarctic Research Programme (FINNARP). The measurements were continued during the 2000/01 season.

\section{METHODS AND STUDY AREA}

Dronning Maud Land is part of East Antarctica, and the measurements were made in its western part, Maudheimvidda (Fig. 1). Two mountain ranges are situated in the area. Vestfjella is a $130 \mathrm{~km}$ long mountain range near the grounding line of the ice sheet flowing toward the Weddell Sea. Heimefrontfjella is situated about $150 \mathrm{~km}$ inland from Vestfjella. This mountain range partly blocks the ice flow from Amundsenisen. RiiserLarsen is a small ice shelf, and Ritscherflya is the ice sheet between two mountain ranges. Blue-ice areas are common throughout the Vestfjella area (Holmlund and Näslund, 1994). Kvitkuven is an ice rise and Högisen is an ice dome located in the area. According to previous studies, accumulation on the Riiser-Larsen Ice Shelf is $0.4 \mathrm{~m}$ w.e., and above the grounding line it is about $0.3 \mathrm{~m}$ w.e. (Isaksson and Karlén, 1994b).

The location of the Finnish research station Aboa, the land routes used and variations in radar backscatter observed in the RADARSAT mosaic (Fig. 1) determined our measurement sites. Snow-pit measurements were made along a $350 \mathrm{~km}$ transect from the seaward edge of the ice shelf to the 


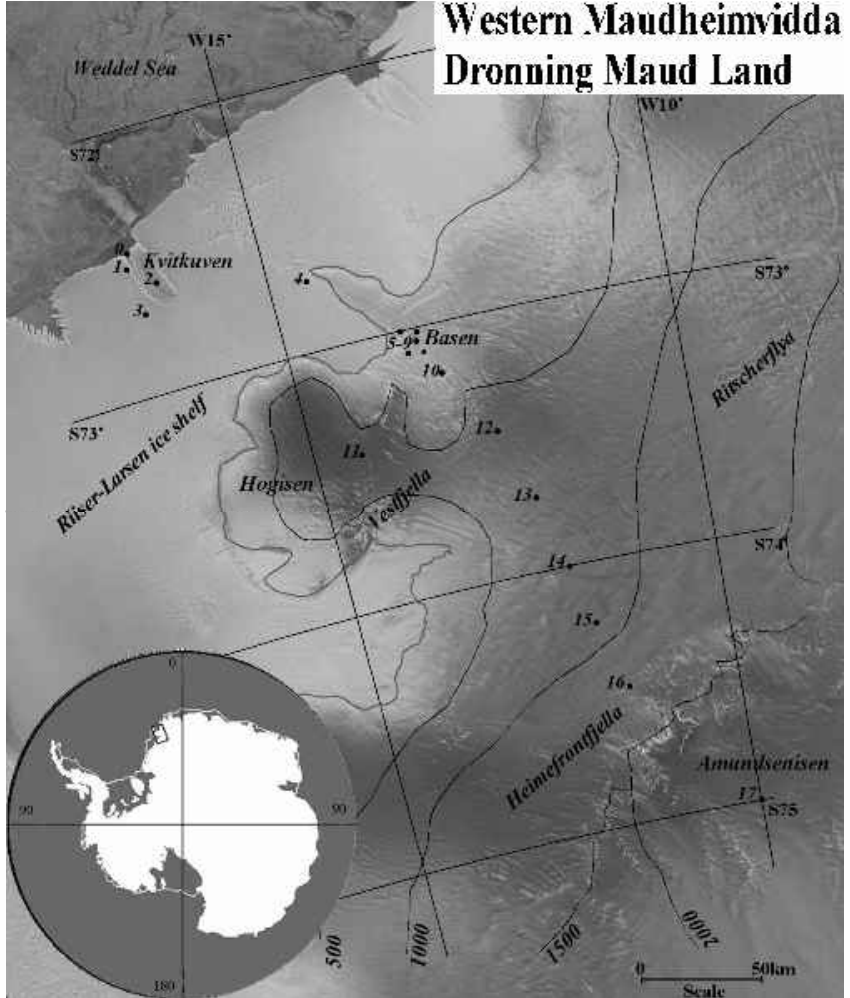

Fig. 1. Location map of Maudheimvidda showing the measurement sites (0-17). Geographic names mentioned in the text are included. Part of a RADARSAT mosaic has been used as a background (RADARSAT data (C) Canadian Space Agency 1997).

Amundsenisen plateau (Fig. 1). Snow-pit coordinates are listed in Table 1. The snow cover on the land-fast sea ice was measured near the ice shelf (site 0 ). The measurements on the continent were made in 17 shallow snow pits with an average depth of about $1.5 \mathrm{~m}$. Two sites were located on the local topographic highs, Kvitkuven and Högisen. At nine sites automated sensors were installed to measure temperature and

Table 1. Site coordinates with altitude and distance from the coast

\begin{tabular}{|c|c|c|c|c|c|}
\hline \multirow[t]{2}{*}{ Site } & \multirow[t]{2}{*}{ Latitude } & \multirow[t]{2}{*}{ Longitude } & \multirow{2}{*}{$\begin{array}{l}\text { Altitude } \\
\text { m a.s.l. }\end{array}$} & \multirow{2}{*}{$\begin{array}{c}\text { Distance from } \\
\text { coast } \\
\mathrm{km}\end{array}$} & \multirow{2}{*}{$\begin{array}{l}\text { Pit depth } \\
\qquad \begin{array}{l}\mathrm{m}\end{array}\end{array}$} \\
\hline & & & & & \\
\hline 0 & $72^{\circ} 29.3^{\prime} \mathrm{S}$ & $16^{\circ} 31.6^{\prime} \mathrm{W}$ & 0 & 0 & 0.25 \\
\hline 1 & $72^{\circ} 32.0^{\prime} \mathrm{S}$ & $16^{\circ} 34.0^{\prime} \mathrm{W}$ & 30 & 3 & 1.0 \\
\hline 2 & $72^{\circ} 36.6^{\prime} \mathrm{S}$ & $16^{\circ} 18.6^{\prime} \mathrm{W}$ & 280 & 15 & 1.5 \\
\hline 3 & $72^{\circ} 40.0^{\prime} \mathrm{S}$ & $16^{\circ} 41.9^{\prime} \mathrm{W}$ & 55 & 20 & 1.0 \\
\hline 4 & $72^{\circ} 45.2^{\prime} \mathrm{S}$ & $14^{\circ} 18.3^{\prime} \mathrm{W}$ & 70 & 75 & 2.0 \\
\hline 5 & $72^{\circ} 58.0^{\prime} \mathrm{S}$ & $13^{\circ} 34.7^{\prime} \mathrm{W}$ & 270 & 110 & 1.5 \\
\hline 6 & $73^{\circ} 02.0^{\prime} \mathrm{S}$ & $13^{\circ} 19.5^{\prime} \mathrm{W}$ & 250 & 120 & 2.0 \\
\hline 7 & $73^{\circ} 03.6^{\prime} \mathrm{S}$ & $13^{\circ} 21.8^{\prime} \mathrm{W}$ & 250 & 120 & 1.0 \\
\hline 8 & $73^{\circ} 05.3^{\prime} \mathrm{S}$ & $13^{\circ} 20.2^{\prime} \mathrm{W}$ & 240 & 120 & 1.2 \\
\hline 9 & $73^{\circ} 04.1^{\prime} \mathrm{S}$ & $13^{\circ} 28.2^{\prime} \mathrm{W}$ & 235 & 125 & 1.5 \\
\hline 10 & $73^{\circ} 12.5^{\prime} \mathrm{S}$ & $13^{\circ} 13.0^{\prime} \mathrm{W}$ & 375 & 140 & 1.5 \\
\hline 11 & $73^{\circ} 26.3^{\prime} \mathrm{S}$ & $14^{\circ} 26.7^{\prime} \mathrm{W}$ & 990 & 130 & 2.0 \\
\hline 12 & $73^{\circ} 27.4^{\prime} \mathrm{S}$ & $12^{\circ} 33.3^{\prime} \mathrm{W}$ & 905 & 170 & 1.5 \\
\hline 13 & $73^{\circ} 43.0^{\prime} \mathrm{S}$ & $12^{\circ} 18.6^{\prime} \mathrm{W}$ & 930 & 195 & 1.1 \\
\hline 14 & $74^{\circ} 01.1^{\prime} \mathrm{S}$ & $12^{\circ} 01.1^{\prime} \mathrm{W}$ & 980 & 230 & 1.5 \\
\hline 15 & $74^{\circ} 14.0^{\prime} \mathrm{S}$ & $11^{\circ} 48.0^{\prime} \mathrm{W}$ & 1000 & 250 & 1.3 \\
\hline 16 & $74^{\circ} 29.0^{\prime} \mathrm{S}$ & $11^{\circ} 33.1^{\prime} \mathrm{W}$ & 1100 & 275 & 2.2 \\
\hline 17 & $74^{\circ} 60.0^{\prime} \mathrm{S}$ & $10^{\circ} 00.5^{\prime} \mathrm{W}$ & 2500 & 355 & 1.6 \\
\hline
\end{tabular}

snow-depth evolution through the winter. The snow-sensor data will be discussed elsewhere; here we will deal only with the results of the snow-pit investigations.

Western Dronning Maud Land has seen several snow studies in previous years. The history of accumulation measurements there, beginning in 1935, is given by Isaksson and Karlén (1994b). Most recently, the Swedish Antarctic Research Programme (SWEDARP) and the European Project for Ice Coring in Antarctica (EPICA) have made accumulation and climate studies (Isaksson and Karlén 1994a, b; Isaksson and others, 1996; Van den Broeke and others, 1999; Karlöf and others, 2000; Sommer and others, 2000). Snow distribution (Richardson and others, 1997) and snow chemistry (Stenberg and others, 1998) were studied from the coast to the polar plateau in the 1990s.

The present snow measurements consist of profiles of temperature, density, grain-size and shape, dielectric constant, wetness and electrical conductivity as well as of the number and position of ice layers, albedo and solarradiation attenuation. At five sites a seasonal oxygen isotope ratio $\left(\delta^{18} \mathrm{O}\right)$ was determined. Most of the profiles were measured in situ at $5-10 \mathrm{~cm}$ intervals, but conductivity and $\delta^{18} \mathrm{O}$ were analyzed from melted samples. Conductivity measured using a hand-held conductivity meter and the conductivity data were used to estimate the salinity of snow on the sea ice. The oxygen isotope analysis was performed at the Laboratory of Isotope Palaeoclimatology, Tallinn Technical University, Estonia. Snow-pit measurements were made using the classical methods. Snow density and other sampling employed a cylindrical snow tube $\left(500 \mathrm{~cm}^{3}\right)$. Samples were weighed using a spring balance. Temperature profiles were measured using a resistance thermometer with a $0.1 \mathrm{~m}$ long temperature probe. The snow-station installation required drilling to about $4.5 \mathrm{~m}$ depth, and temperatures from the bottom were measured immediately upon extraction of firn cores. Snow grains were photographed using a special camera stand (Pihkala and Spring, 1985), and grain diameter and shape were determined from the photographs. The dielectric constant was measured with a LEAS's TEL 051 dielectric probe. The relative permittivity $\varepsilon=\varepsilon^{\prime}-j \varepsilon^{\prime \prime}(j=\sqrt{-1})$ is a complex quantity, where $\varepsilon^{\prime}$ and $\varepsilon^{\prime \prime}$ are the dielectric constant and the dielectric loss factor (Hallikainen and Winebrenner, 1992). Surface albedo was measured with a Middleton EP16 pyranoalbedometer, sensitive from 300 to $3000 \mathrm{~nm}$, measuring both downwelling and upwelling irradiance simultaneously. The spectral attenuation of solar radiation was measured using an ASD Personal Spectrometer II from 350 to $1050 \mathrm{~nm}$ in semi-infinite snow cover, i.e. snow of sufficient thickness that the measured signals are independent of the underlying surface (Brandt and Warren, 1993). To measure attenuation, a fibre-optic probe was inserted progressively into the snow, and spectra were acquired at approximately $10 \mathrm{~cm}$ intervals. The geographic positions of the measurement sites were determined by a hand-held global positioning system (Garmin) with an accuracy of $\pm 100 \mathrm{~m}$.

\section{RESULTS AND DISGUSSION}

Table 2 summarizes our measurements. Figure 2 displays the variations in first-metre mean values of grain-size, conductivity and number of ice layers with distance from the coast. The dielectric constants seen in Figure 2 are from the surface, and the low values seen in the graph are from 
Table 2. Summary of measurements. Mean values, standard deviations (S.D.) and standard errors (S.E.) have been calculated

\begin{tabular}{|c|c|c|c|c|c|c|c|c|c|}
\hline Site & $\begin{array}{c}\text { Temperature } \\
\text { gradient } 30-100 \mathrm{~cm} \\
{ }^{\circ} \mathrm{C} \mathrm{cm}^{-1}\end{array}$ & $\begin{array}{l}\text { Density } \\
0-100 \mathrm{~cm} \\
\mathrm{~kg} \mathrm{~m}^{-3}\end{array}$ & $\begin{array}{c}\text { Grain diameter } \\
\mathrm{mm}\end{array}$ & $\begin{array}{l}\text { Surface dielec- } \\
\text { tric constant }\end{array}$ & $\begin{array}{l}\text { Conductivity } \\
0-100 \mathrm{~cm} \\
\mu \mathrm{S} \mathrm{cm}^{-1}\end{array}$ & $\begin{array}{l}\text { Numbers of } \\
\text { layers } \\
\mathrm{m}^{-1}\end{array}$ & $\begin{array}{c}\delta^{18} \mathrm{O} \\
0-100 \mathrm{~cm} \\
\% 0\end{array}$ & Albedo & $\begin{array}{l}\text { Approx. accum. } \\
\text { mm w.e. }\end{array}$ \\
\hline 1 & -0.05 & 420 & 5 & 2.07 & 99.4 & 6 & - & 0.85 & 340 \\
\hline 2 & -0.05 & 390 & - & 1.44 & 13.2 & 3 & -16.46 & - & 260 \\
\hline 3 & -0.07 & 445 & 2 & 1.89 & 16.9 & 2 & - & 0.86 & \\
\hline 4 & -0.07 & 415 & 1 & 1.65 & 5.7 & 0 & - & 0.86 & \\
\hline 5 & -0.06 & 425 & 1 & 1.83 & 4.7 & 2 & -20.55 & 0.82 & 335 \\
\hline 6 & -0.07 & 395 & 1.5 & - & - & - & - & 0.88 & \\
\hline 7 & -0.03 & 400 & 1.25 & 1.75 & 15.8 & 5 & - & - & \\
\hline 8 & -0.04 & 465 & 0.75 & 1.81 & 9.9 & 2 & -26.14 & - & 230 \\
\hline 9 & -0.03 & 390 & - & 1.71 & - & 5 & - & - & \\
\hline 10 & -0.02 & 435 & 1.5 & 1.85 & 4.8 & 7 & - & 0.81 & \\
\hline 11 & -0.04 & 320 & 1.5 & 1.34 & 4.3 & 0 & -19.25 & - & \\
\hline 12 & -0.04 & 410 & 1 & 1.71 & 6.5 & 8 & - & 0.81 & \\
\hline 13 & -0.05 & 425 & 1 & - & 4.9 & 7 & - & - & \\
\hline 14 & -0.05 & 430 & - & 1.65 & 7.6 & 9 & -29.91 & 0.86 & 160 \\
\hline 15 & -0.05 & 425 & - & 1.71 & - & 10 & - & - & \\
\hline 16 & -0.07 & 390 & 1.25 & 1.69 & 3.4 & 8 & - & 0.85 & \\
\hline 17 & -0.07 & 380 & - & - & 2.3 & 8 & - & - & 100 \\
\hline Mean & -0.05 & 409 & 1.6 & 1.72 & $7.7 *$ & 5 & -22.46 & 0.84 & \\
\hline S.D. & 0.02 & 32 & 1.1 & 0.2 & 4.8 & 3 & 5.45 & 0.03 & \\
\hline S.E. & 0.005 & 8 & 0.3 & 0.05 & 1.3 & 1 & 2.44 & 0.01 & \\
\hline
\end{tabular}

* Site 1 has been left out from the mean value.
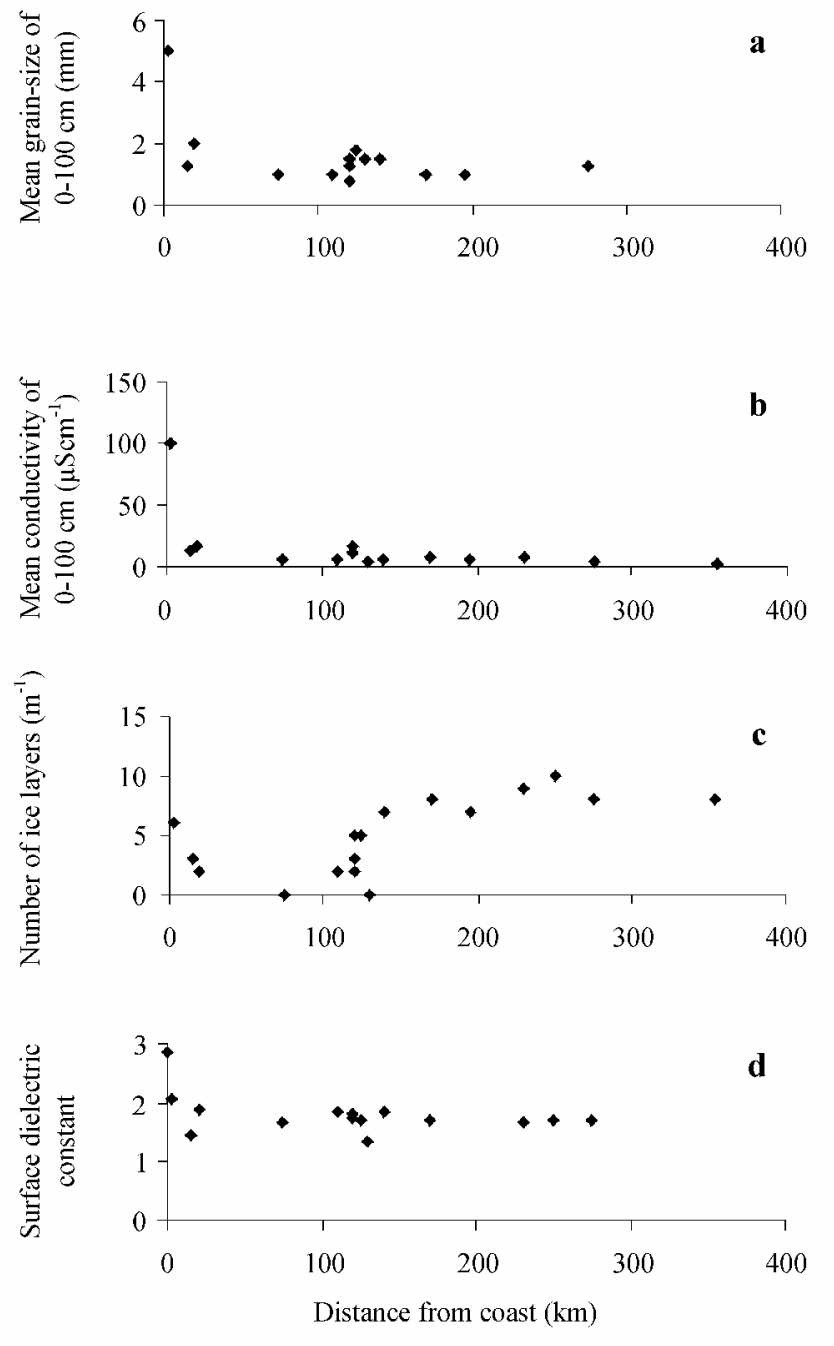

Fig. 2. Variations of snow properties with distance from the coast. Mean values measured in the upper first metre for grain-size (a), conductivity (b) and number of ice layers (c). (d) Surface dielectric constant values vs distance from the coast. the local topographic highs. The first value of the dielectric constant is from the snow on the sea ice. Grain-size was largest on the seaward edge of the ice shelf. Near the coast there were thick $(1-5 \mathrm{~cm})$ ice layers, but above the grounding line there were many thin $(0.5-2 \mathrm{~mm})$ ice layers in the first metre of snowpack. On the Högisen ice dome there were no ice layers in the first metre of snow. The first value of conductivity is from the edge of the ice shelf. On the sea ice conductivity of snow was $3.9 \mathrm{mS} \mathrm{cm}^{-1}$.

\section{Snow temperature, density and accumulation}

Temperatures (depth $0-1 \mathrm{~m}$ ) show strong negative correlation with elevation $(r=-0.92)$ and also with distance from the coast $(r=-0.88)$. Daily temperature variations were significant down to about $30 \mathrm{~cm}$ depth. The temperature gradient in the interval $30-150 \mathrm{~cm}$ was $-0.05^{\circ} \mathrm{C} \mathrm{cm}^{-1}$, and in the interval $150-400 \mathrm{~cm}$ was $-0.02^{\circ} \mathrm{C} \mathrm{cm}^{-1}$.

During the 1999/2000 season the mean density in the first metre with the standard error was $409 \pm 8 \mathrm{~kg} \mathrm{~m}^{-3}$; on the ice shelf it was $427 \pm 9 \mathrm{~kg} \mathrm{~m}^{-3}$ and on the local topographic highs it was $340 \mathrm{~kg} \mathrm{~m}^{-3}$. Only the density profiles from the ice dome and the ice rise had a clear increase of density with depth in the first $150 \mathrm{~cm}$. According to Kojima (1964), surface density is typically about $300-400 \mathrm{~kg} \mathrm{~m}^{-3}$, while at $10 \mathrm{~m}$ density it is $500-600 \mathrm{~kg} \mathrm{~m}^{-3}$. According to Isaksson and Karlén (1994b), in 1989 the mean annual density in the same area from the coast to Heimefrontfjella was $412 \mathrm{~kg} \mathrm{~m}^{-3}$ and from Vestfjella to Heimefrontfjella it was $397 \mathrm{~kg} \mathrm{~m}^{-3}$. Gjessing and Wold (1986) have measured densities in the uppermost $3 \mathrm{~m}$ of the Riiser-Larsen Ice Shelf of $470-510 \mathrm{~kg} \mathrm{~m}^{-3}$. They also measured the lowest values at the top of the Kvitkuven ice rise. In Kemp Land in Antarctica snow densities of $398-438 \mathrm{~kg} \mathrm{~m}^{-3}$ have been observed in the uppermost $2 \mathrm{~m}$ (Goodwin and others, 1994).

The $\delta^{18} \mathrm{O}$ values, measured for five different sites, cover only slightly more than one annual cycle (Table 2). For such 
a short period, many errors are possible in the estimation of seasonal accumulation. For example, the surface roughness or micro-relief due to snow dunes and sastrugi can be equivalent to or greater than 1 year's snow accumulation (Goodwin and others, 1994), so the annual cycle may be distorted, and the values may be biased by evaporation processes during snowdrifting. This may apply to the mean $\delta^{18} \mathrm{O}$ values in Table 2. The approximate annual accumulation, based on snow-pit and $\delta^{18} \mathrm{O}$ data, is also given in Table 2. The values are in good general agreement with previous accumulation measurements in the area (Isaksson and Karlén, 1994a,b; Isaksson and others, 1996). On Kvitkuven the accumulation was lower than on the ice shelf nearby. Gjessing and Wold (1986) also concluded that the mean accumulation was lower on Kvitkuven than on the rest of the ice shelf.

\section{Layering and snow grains}

The snow cover contains numerous thin ice layers and crusts (0.5-2 mm), which, according to Goodwin (1991), form at the surface in summer due to strong incident solar radiation and wind. Some subsurface melting occurs, but evaporation crusts dominate inland. Wind crust forms by the action of the wind on the surface. Because of low inland precipitation, the vertical distance between ice layers is small and there are many such layers in the first metre of the snowpack. Near the coast, summer melting and thick melt-freeze ice layers $(1-5 \mathrm{~cm})$ occur. The snowpack is layered also as a result of snow transport by the wind. According to MosleyThompson and others (1985), a high-density layer with fine grains forms in winter, while summer layers have lower density and bigger grains. Metamorphism is mainly caused by temperature gradient and diffusion of water vapour. Depth hoar is an annual phenomenon according to MosleyThompson and others (1985). Loose, big-grained depth-hoar layers were found usually beneath ice layers.

In Antarctica, snow grains are rounded at a very early stage because of wind fragmentation and radiation, and they can be classified as big well-rounded particles according to Colbeck and others (1990). Near the coast there were also rounded polycrystals as a result of melt-freeze cycles. On Högisen (site 8), grains with fragments of relatively intact precipitation particles were found down to $60 \mathrm{~cm}$ depth. The snow in this location was less densely packed, being apparently less affected by katabatic winds. The average grain diameter over the entire transect was $1.5-2 \mathrm{~mm}$ in the upper first metre and at the surface $1 \mathrm{~mm}$. In Figure 3, snow grains from measurement sites 1, 9 and 11 (Fig. 1) can be seen. Site 1 was located near the edge of the ice shelf. Grains from $20 \mathrm{~cm}$ depth are rounded polycrystals. Site 9 was located near the Basen nunatak, and wellrounded grains from that site are from $20 \mathrm{~cm}$ depth, representing the most common grain shape. Site 11 is located on Högisen. The photographs are from the surface and from $60 \mathrm{~cm}$ depth. Fragments of precipitation particles can still be seen. Dahe and others (1988) studied the growth rate of grains, and in the upper 5-7 m observed values were about 1.5-3 times those below $5 \mathrm{~m}$. They measured the grain area, which varied through $0.1-0.2 \mathrm{~mm}^{2}$ close to the surface and $0.2-3 \mathrm{~mm}^{2}$ at $10 \mathrm{~m}$ depth. In Kemp Land, grain diameters varied from 0.7 to $>2 \mathrm{~mm}$, with small near-surface grains and bigger depth-hoar crystals (Goodwin and others, 1994).

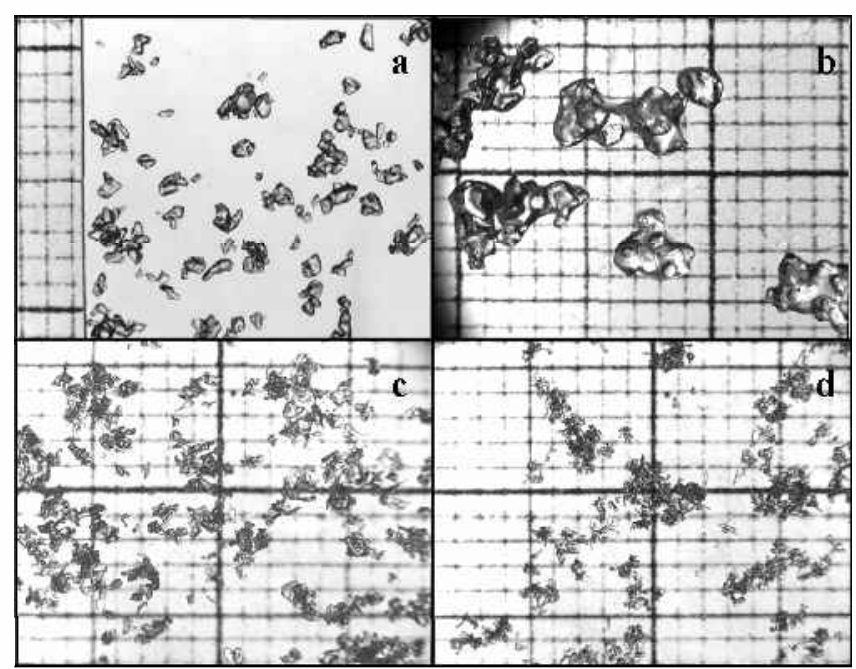

Fig. 3. Snow grains from three different sites: ( a) well-rounded particles at $20 \mathrm{~cm}$ depth from site 9; (b) rounded polycrystals at $20 \mathrm{~cm}$ depth from site 1; (c) surface grains with the fragments of precipitation particles from site 11; and (d) grains at $60 \mathrm{~cm}$ depth from site 11. Fragments of precipitation particles can be seen. The background grid is a millimetre scale.

\section{Electrical properties}

The surface dielectric constant was $\varepsilon^{\prime}=1.72 \pm 0.05$, while in the upper first metre it was $1.81 \pm 0.02$. In the snow on sea ice the dielectric constant was 2.9. The snow cover can contain liquid water at temperatures near $0^{\circ} \mathrm{C}$, and this strongly affects its dielectric constant. Excepting the coastal areas in summer, the snow cover of Antarctica can be considered to be dry. The dielectric constant of snow also depends on its density and crystal shape (Hallikainen and Winebrenner, 1992). Our measured dielectric constants were related to snow density $\rho\left(\mathrm{g} \mathrm{cm}^{-3}\right)$ by $\varepsilon^{\prime}=0.9+2.2 \rho$, which is close to the empirical formula $\varepsilon^{\prime}=1.0+2.1 \rho$ given by Ulaby and others (1986). The mean wetness expressed in per cent by volume was $0.9 \pm 0.1 \%$. The mean conductivity of the upper first metre was $7.7 \pm 1.3 \mu \mathrm{S} \mathrm{cm}^{-1}$ if we leave out the edge of the ice shelf (site 1) where the value was considerably higher than elsewhere (Table 2).

In the 1997 RADARSAT mosaic from the Antarctic Mapping Mission (200 $\mathrm{m}$ resolution) a significantly lower backscatter coefficient is observed for Högisen and Kvitkuven (Fig. 1). Both are local topographic highs with less dense snow and a lower dielectric constant than was found elsewhere along our transect. The snow surface was smoother than in nearby valleys, apparently due to lighter wind action.

\section{Radiation measurements}

The albedo for the measured 10 sites on the glacier was $0.84 \pm 0.01$; for snow-covered sea ice the albedo was 0.77 . Light penetration into the snow cover is important as it is indicative of the energy available to drive snow metamorphism, internal melt and photochemical processes within the snowpack (Brandt and Warren, 1993). For our analysis the spectral interval was limited to $400-900 \mathrm{~nm}$ as the signalto-noise ratio was too low outside this interval. Transmission factors were estimated from the ratio of upwelling radiance at depth to the upwelling radiance at the surface, assuming Lambertian reflectance at all depths. For semi-infinite snow 


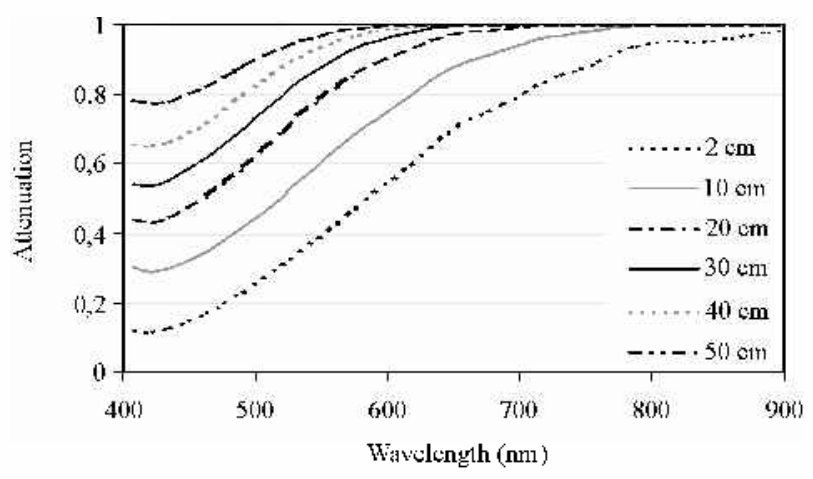

Fig. 4. Spectral attenuation for various sampling depths in semi-infinite snow at site 6 .

(Fig. 4) the attenuation is strongest in the top few centimetres of the snowpack and decreases exponentially with increasing depth. In the top curves, the attenuation is strongest in the near-infrared. Deeper into the snow, longer wavelengths are extinguished, as predicted and observed by Brandt and Warren (1993). The lowest attenuation occurs around 420-470 nm. In Figure 5, extinction coefficients are computed using Bouguer-Lambert's law for a waveleng th of $470 \mathrm{~nm}$ at site 5 . The extinction coefficient was averaged for the different depths sampled and the mean value was calculated. The hypothesis that the extinction coefficient decreases with increasing grain-size (Warren, 1982) was evaluated. The extinction coefficient was averaged for every sampled depth and plotted vs the associated grain-size from snow-pit measurements. The correlation was found to be site-specific as seen in Figure 5. The mean extinction coefficient for semi-infinite snow was $0.11 \mathrm{~cm}^{-1}$. This is in accordance with results by Liljequist (1956), Grenfell and Maykut (1977) and Grenfell (1979).

\section{Snow zones from coast to inland}

According to our measurements, five snow zones can be suggested.

(1) The saline snow cover on sea ice is mostly thin, annual and has high conductivity $\left(3.9 \mathrm{mS} \mathrm{cm}^{-1}\right)$ and dielectric constant (2.9). The snow thickness at site 0 in this zone was $25 \mathrm{~cm}$, the mean density was $413 \mathrm{~kg} \mathrm{~m}^{-3}$ and the mean salinity was 2 ppt. Flooding of sea water onto sea ice, capillary effects and redistribution of snow by wind cause the snow to become saline (Granberg, 1998). This modifies snow dielectric properties, grain-size distribution, melting point and the degree of bonding between ice and snow (Massom and others, 1997). Our measurements were

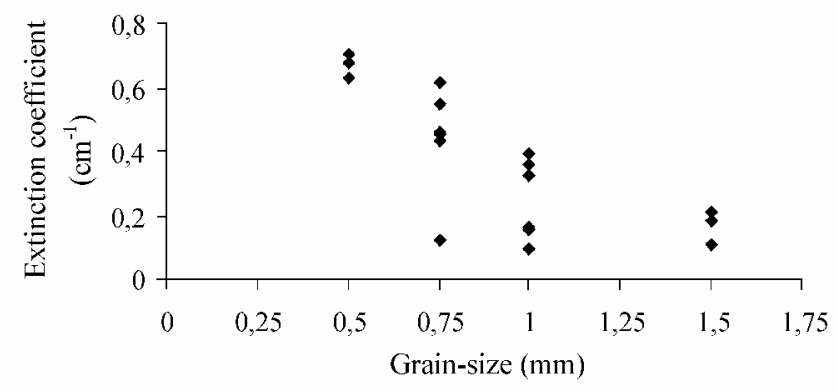

Fig. 5. Extinction coefficient vs grain-size in semi-infinite snow at site 5 . made in the middle of the warm season. Worby and others (1998) report, based on results from two voyages in East Antarctic sea ice (May 1993 and August 1995), a mean snow density of approximately $400 \mathrm{~kg} \mathrm{~m}^{-3}$ and a mean salinity of $8.5 \pm 11.5 \mathrm{ppt}$. Studies in the Weddell Sea in mid-winter give a mean density of $320 \pm 90 \mathrm{~kg} \mathrm{~m}^{-3}$ and a mean salinity of $8.68 \pm 10.7 \mathrm{ppt}$ (Massom and others, 1997).

(2) The seaward edge of the ice shelf experiences melting during the summer months. During the season low clouds were often observed locally near the edge of the shelf, giving a much less negative thermal radiation balance there than just a few tens of kilometres inland. This may contribute to a greater incidence of surface melt in this zone. Accordingly, the snow cover in this zone is very hard and dense, with higher conductivity than further inland and ice layers $1-5 \mathrm{~cm}$ thick, enabling identification of the summer layer. Generally, snow grains are larger in this zone than elsewhere.

(3) In the inner parts of the ice shelf some melting also occurs. The snow is hard and dense, with occasional thick ice layers. However, grain-size is smaller than near the seaward edge of the ice shelf.

(4) The snow above the grounding line and behind the first mountain range is not as hard and dense as on the ice shelf, and is more uniform in the vertical sense. Thin ice layers $(0.5-2 \mathrm{~mm})$ are observed. The annual accumulation decreases with distance from the coast. In the measurement area the grounding line is situated close to the Vestfjella mountain range.

(5) The local topographic highs are an exception. The snow surface is smoother and the snow has a lower density and dielectric constant. There are very few ice layers, and precipitation particles keep their form. Local topographic highs channel the katabatic outflow and are not as strongly affected by katabatic winds as nearby glaciers.

\section{GONGLUSIONS}

Spatial variations in physical properties of the snow cover have been measured from the coastal region to the polar plateau along a $350 \mathrm{~km}$ line. Measurements were made in shallow snow pits using classical methods. Generally on the ice shelf the snow cover was more layered compared to more uniform snow above the grounding-line area.

Snow-pit studies suggested five principal snow zones in the measurement area. Annual, thin and saline (2 ppt) snow on sea ice has high conductivity $\left(3.9 \mathrm{mS} \mathrm{cm}^{-1}\right)$ and dielectric constant (2.9). On the seaward-edge zone of the ice shelf, summer melting occurs, forming dense snow with thick ice layers $(1-5 \mathrm{~cm})$ and big polycrystals $(5 \mathrm{~mm})$. Snow near the edge of the ice shelf has higher conductivity $\left(99.9 \mu \mathrm{S} \mathrm{cm}^{-1}\right)$ and dielectric constant (2.1) than further inland. In the inner parts of the ice shelf, snow is hard and dense, and occasionally some thick ice layers occur. On the ice shelf, snow is denser $\left(427 \pm 9 \mathrm{~kg} \mathrm{~m}^{-3}\right)$ than behind the first mountain range. The snow cover above the grounding line was more uniform, having thin ice layers $(0.5-2 \mathrm{~mm})$ instead of thick ones. Surface slope in the grounding-line area reduces precipitation and accumulation inland (Bromwich, 1988). Accumulation varied from approximately 340 to $100 \mathrm{~mm}$ w.e. from the seaward edge of the ice 
shelf to the polar plateau. Local topographic highs differ most from the other snow environments, having smoother surface, less dense snow $\left(340 \mathrm{~kg} \mathrm{~m}^{-3}\right)$ and lower dielectric constant (1.4) compared to nearby glaciers.

Based on data for only one season it is difficult to say if these snow zones recur every year. Seasonal snow properties depend strongly on meteorological factors, notably wind and solar radiation, but the uniqueness of Antarctic snow is probably first related to the dryness of the air descending into the Antarctic anticyclone.

The measurements suggest that local topography and distance from the coast and moisture source have an effect on snow properties. In Antarctica an increase in distance from the coast also means an increase in surface elevation. Both influence snow properties. Topographic effects on the katabatic winds also appear important.

\section{ACKNOWLEDGEMENTS}

Academy of Finland finances the "Seasonal Snow in Antarctica" project (Academy project No. 43925 to M. Leppäranta). CARTEL provided some of the equipment, and Université de Sherbrooke the salary of H. B. Granberg. Logistics were provided by FINNARP. We are grateful to T. Martma of the Laboratory of Isotope Palaeoclimatology, Tallinn, for the isotope analyses. We thank E. Isaksson, J.-G. Winther and an anonymous referee for their comments and suggestions. K. C. Jezek from the Byrd Polar Research Center, Colombus, OH, provided a copy of the Antarctic RADARSAT mosaic (C Canadian Space Agency 1997).

\section{REFERENGES}

Bailey, D. A. and A. H. Lynch. 2000a. Development of an Antarctic regional climate system model. Part I: sea ice and large-scale circulation. 7. Climate, 13(8), 1337-1350.

Bailey, D. A. and A. H. Lynch. 2000b. Development of an Antarctic regional climate system model. Part II: station validation and surface energy balance. f. Climate, 13(8), 1351-1361.

Bindschadler, R. 1998. Monitoring ice sheet behavior from space. Rev. Geophys., 36(1), 79-104.

Bintanja, R. and M. R. van den Broeke. 1995. The surface energy balance of Antarctic snow and blue ice. 7. Appl. Meteorol., 34(4), 902-926.

Brandt, R. E. and S. G. Warren. 1993. Solar-heating rates and temperature profiles in Antarctic snow and ice. F. Glaciol., 39(131), 99-110.

Bromwich, D. H. 1988. Snowfall in high southern latitudes. Rev. Geophys., 26(1), 149-168.

Colbeck, S. C. and 7 others. 1990. The international classification for seasonal snow on the ground. Wallingford, Oxon, International Association of Scientific Hydrology. International Commission on Snow and Ice.

Gjessing, Y. and B. Wold. 1986. Absolute movements, mass balance and snow temperatures of the Riiser-Larsenisen Ice Shelf, Antarctica. Nor. Polarinst. Skr. 187, 23-31.

Goodwin, I. D. 1991. Snow-accumulation variability from seasonal surface observations and firn-core stratigraphy, eastern Wilkes Land, Antarctica. 7. Glaciol., 37(127), 383-387.

Goodwin, I. D., M. Higham, I. Allison and Ren Jiawen. 1994. Accumulation variation in eastern Kemp Land, Antarctica. Ann. Glaciol., 20, 202-206.

Granberg, H. B. 1998. Snow cover on sea ice. In Leppäranta, M., ed. Physics of ice-covered seas. Vol. 2. Helsinki, University of Helsinki. Department of Geophysics, 605-649.

Grenfell, T. C. 1979. The effects of ice thickness on the exchange of solar radiation over the polar oceans. F. Glaciol., 22(87), 305-320.
Grenfell, T. C. and G. A. Maykut. 1977. The optical properties of ice and snow in the Arctic Basin. F. Glaciol., 18(80), 445-463.

Hallikainen, M. and D. Winebrenner. 1992. The physical basis for sea ice remote sensing. In Carsey, F. D. and 7 others, eds. Microwave remote sensing of sea ice. Washington, DC, American Geophysical Union, 29-46. (Geophysical Monograph Series 68.)

Holmlund, P. and J.-O. Näslund. 1994. The glacially sculptured landscape in Dronning Maud Land, Antarctica, formed by wet-based mountain glaciation and not by the present ice sheet. Boreas, 23(2), 139-148.

Isaksson, E. and W. Karlén. 1994a. High resolution climatic information from short firn cores, western Dronning Maud Land, Antarctica. Climatic Change, 26(4), 421-434.

Isaksson, E. and W. Karlén. 1994b. Spatial and temporal patterns in snow accumulation, western Dronning Maud Land, Antarctica. 7. Glaciol., 40(135), 399-409.

Isaksson, E., W. Karlén, N. Gundestrup, P. Mayewski, S. Whitlow and M. Twickler. 1996. A century of accumulation and temperature changes in Dronning Maud Land, Antarctica. 7. Geophys. Res., 101(D3), 7085-7094.

Karlöf, L. and 12 others. 2000. A 1500 year record of accumulation at Amundsenisen, western Dronning Maud Land, Antarctica, derived from electrical and radioactive measurements on a $120 \mathrm{~m}$ ice core. $\mathcal{F}$. Geophys. Res., 105(D10), 12,471-12,483.

Kojima, K. 1964. Densification of snow in Antarctica. In Mellor, M., ed.Antarctic snow andice studies. Washington, DC, American Geophysical Union, 157-218. (Antarctic Research Series 2.)

Liljequist, G. H. 1956. Energy exchange of an Antarctic snow-field. Shortwave radiation (Maudheim $71^{\circ} 03^{\prime} \mathrm{S}, 10^{\circ} 56^{\prime} \mathrm{W}$ ). Norwegian-BritishSwedish Antarctic Expedition, 1949-52. Sci. Results II, Part 1A, 1-109.

Massom, R. A., M. R. Drinkwater and C. Haas. 1997. Winter snow cover on sea ice in the Weddell Sea. F. Geophys. Res., 102(Cl), 1101-1117.

Mosley-Thompson, E., P. D. Kruss, L. G. Thompson, M. Pourchet and P Grootes. 1985. Snow stratigraphic record at South Pole: potential for paleoclimatic reconstruction. Ann. Glaciol., 7, 26-33.

Orheim, O. and B. K. Lucchitta. 1988. Numerical analysis of Landsat Thematic Mapper images of Antarctica: surface temperatures and physical properties. Ann. Glaciol., 11, 109-120.

Orheim, O. and B. Lucchitta. 1990. Investigating climate change by digital analysis of blue ice extent on satellite images of Antarctica. Ann. Glaciol., 14, 211-215.

Pihkala, P. and E. Spring. 1985. A practical method for photographing snow samples Helsinki, University of Helsinki. Department of Geophysics. (Report Series in Geophysics 20.)

Richardson, G., E. Aarholt, S.-E. Hamran, P. Holmlund and E. Isaksson. 1997. Spatial distribution of snow in western Dronning Maud Land, East Antarctica, mapped by a ground-based snow radar. 7. Geophys. Res., 102(B9), 20,343-20,353

Smith, I. N., W. F. Budd and P. Reid. 1998. Model estimates of Antarctic accumulation rates and their relationship to temperature changes. Ann. Glaciol., 27, 246-250.

Sommer, S. and 9 others. 2000. Glacio-chemical study spanning the past $2 \mathrm{kyr}$ on three ice cores from Dronning Maud Land, Antarctica. 1. Annually resolved accumulation rates. F. Geophys. Res., 105(D24), 29,411-29,421.

Stenberg, M. and 7 others. 1998. Spatial variability of snow chemistry in western Dronning Maud Land, Antarctica. Ann. Glaciol., 27, 378-384.

Ulaby, F.T., R. K. Moore and A. K. Fung. 1986. Microwave remote sensing, active and passive. Vol. 3. From theory to applications. Reading, MA, AddisonWesley Publishing Co.

Van den Broeke, M. R. and R. Bintanja. 1995. The interaction of katabatic winds and the formation of blue-ice areas in East Antarctica. f. Glaciol., 41 (138), 395-407.

Van den Broeke, M. R. and6 others. 1999. Climate variables along a traverse line in Dronning Maud Land, East Antarctica. J. Glaciol., 45(150), 295-302.

Warren, S. G. 1982. Optical properties of snow. Rev. Geophys. Space Phys., 20(1), 67-89.

Winther, J.-G. 1993. Studies of snow surface characteristics by Landsat TM in Dronning Maud Land, Antarctica. Ann. Glaciol., 17, 27-34.

Worby, A. P., R. A. Massom, I. Allison, V. I. Lytle and P. Heil. 1998. East Antarctic sea ice: a review of its structure, properties and drift. InJeffries, M. O., ed. Antarctic sea ice: physical processes, interactions and variability. Washington, DC, American Geophysical Union, 41-67. (Antarctic Research Series 74.) 